was materially weakened. The present writer takes these circumstances into account. He farther uses the information with which modern travellers have furnished us as to the physical and botanical geography of Palestine, including the data obtained from thermometric registers at Jerusalem and elsewhere; and he arrives at the following conclusions :-

1. That judging from the known thermometric conditions of the growth and maturity of the date palm, compared with the evidences in Scripture of its distribution and culture in Ancient Palestine, the mean temperature of the site of Jerusalem, when reduced to the level of the sea, can have then differed but little from $70^{\circ}$ Fahrenheit, which is its present value according to the best authorities. We conclude, with still more certainty, that the temperature could not, anciently, have been colder than this.

2. That comparing the conditions which limit the cultivation of the vine, we find that as it certainly was not anciently less, but more general and advantageous than at present, the climate of Palestine could not have been materially hotter than now belongs to its geographical position, taking also into account the modifying influence of height above the sea.

3. That this argument is enhanced by the evidence from hieroglyphics, and also from Scripture, that the cultivation of the grape was anciently more extensive in Egypt than it now is. That while this might seem to point to the conclusion that these countries are hotter now than formerly, the difference is sufficiently accounted for by political circumstances, and the conclusion is itself negatived by the evidence to the contrary derived from the date palm.

4. Hence the climate of Palestine, being neither sensibly hotter nor colder than it anciently was, is of course unchanged; and the direct evidence of modern travellers on the distribution of the vine and palm in that country leads to the same result.

\title{
2. Biographical Notice of Andrew Dalzel, Professor of Greek in the University of Edinburgh. By Professor Innes.
}

Professor Dalzel was born in 1742, at Gateside of Newliston. His father died while he was still an infant, and he was educated partly by his uncle, the minister of Stonykirk, in Galloway, and after his death, by his mother, at Newliston. He attended the 
parish school of Kirkliston, and from thence went to college at Edinburgh. His companion at both was Robert Liston, afterwards Sir Robert, the ambassador. The boys began life together. Liston was just two days younger than his friend, and the intimacy of school and college lasted through life. It is chiefly from the correspondence kept up between them from 1766 till 1805 that the present Memoir has been compiled.

On leaving college, Dalzel was for some time tutor in the family of Lauderdale, and the friendship so commenced also remained firm and unbroken through life.

In $1772-73$, partly by an arrangement with his predecessor, partly through the influence of the Lauderdales with the Town Council, Dalzel became Professor of Greek in the University. The study of that language had fallen much into decay in Scotland, and Dalzel set himself zealously to the task of restoring and promoting it. He devoted himself to the duties of his class, and was soon rewarded by its increase in numbers and improvement in study. Among other means for his object, he set about preparing some class-books for Greek students which were then unknown. His first publication was a little supplement to Moor's Grammar, under the title of Fragmenta Grammatices Graca in usum tironum in literis Gracis in Academia Edinensi. The prose volume of his wellknown Collectanea Majora was published in 1785, and got almost at once into favour with the best teachers here and in England.

In the immediate duties of his professorship Dalzel was indefatigable. Dr Monro said of him, that " he had more to brag of than any man in the college, for that Greek was going fast downhill till he revived it." His second volume, the poetical portion of the Collectanea Majora, cost him great labour, and obtained the assistance of many friends among the best scholars of England. Though long promised and urgently called for by the schoolmasters and "the trade," it was not published till 1797. It was then received with as much favour as its predecessor; and the two volumes rapidly came to supersede all other class-books for Greek students. Both volumes passed through many editions, and perhaps wanted nothing for permanent success and popularity, but that the valuable information conveyed in the notes should have been given in English instead of Latin, which the practice of the time seemed to require. 
Dalzel married, in 1786, Anne, daughter of Dr John Drysdale, the well known clerk of the General Assembly, and one of the leaders of the Church. His marriage connected him with the Adams, Principal Robertson, the Kennedys of Dunure, the Broughams, Elliots of Minto, and the rest of that remarkable group of Edin. burgh families. His professorial position brought him into intimate acquaintance with the philosophers and scholars who then made our University famous. His labours in publishing books for his class, connected him with many distinguished scholars; and a good deal of his correspondence is preserved and used for this Memoir. It embraces letters from Heyne, Böttiger, Porson, Parr, Bishop Burgess, Dr Raine of the Charterhouse, Tate, the excellent master of Richmond school, Thomas Young, the scientific philosopher and universal scholar.

The Memoir has frequent notices of the commencement and progress of the University buildings, and other academic matters; including the first Symposium Academicum, the death and character of Principal Robertson, the commencement of the Society of Antiquaries, and in connection with it, the foundation of the Royal Society, of which Dalzel was an original and active member. It notices also some passing events; such as visits of remarkable persons to Edinburgh, the impression made by Burke, by Burns, by Mrs Siddons, \&c.

But the chief object of the Memoir, as of Dalzel's whole life, is the restoration of Greek and classical education in Scotland. The writer gives his reasons for preferring a classical discipline to either a purely metaphysical or a merely physical course of education, formerly and now preferred among us.

Dalzel's character was singularly amiable. Living in factious and contentious times, in a society not always peaceful, he courageously avcided all quarrels, and gave his whole energy to his duty. In society and his family he was equally fortunate and beloved; and his life is an example of happiness uninterrupted, arising from successful devotion of talents to a worthy object. Dalzel died on the 8th December 1806.

The following Gentlemen were admitted Fellows of the Society :-

Henky Cheyne, Esq., W.S.

Rev. W. G. Buatkie, M.A. 
The following Donations to the Library were announced:Annales Hydrographiques. Tome VI.-VIII. 8vo.-From the Depôt de la Marine.

Instructions Nautiques sur les Mers de l'Inde. Par J. Horsburgh. Tome III., 2nd partie. 1860. 4to.-From the same.

Mer du Nord, Troisième partie. Côtes Est d'Angleterre. 1860. -From the same.

Description Hydrographique des Côtes Septentrionales de la Russie. Par M. Reineke. Première partie. Mer Blanche. 8vo. 1860. -From the same.

Catalogue par Ordre Geographique des Cartes, Plans, Vues de Côtes, Memoires, Instructions Nautiques, \&c., qui composent l'Hydrographie Française. 8ซo. 1860.-From the same.

Catalogue Chronologique des Cartes, Plans, Vues de Côtes, \&cc.8vo. 1860.-From the same.

Renseignements Hydrographiques sur la Mer de Chine, la Coree, la Mer et les Iles du Japon. 8vo. 1860.-From the same.

Instructions Nautiques sur les Traverses d'Aller et de Retour de la Manche à Java. 4to. 1861.-From the same.

Detroit de Banka. Nouvelle Passe pour donner dans le Detroit en venant du Sud. 8vo. 1860.-From the same.

Influence des Courants sur la Narigation a la Côte Occidentale d'Afrique. Par M. Vallon. 8vo. 1860.-From the same.

Description des Basses et des Dangers, qui sont près de la Còte S.E. de l'Ile de Ceylan. 8vo. 1861.-From the same.

Notice sur la Carte des Environs de Cherbourg. Par M. Keller. 8vo. 1861.-From the same.

Note sur l'Evaluation des Distances en Mer. Par M. de la Roche-

Poncie. 8vo. 1860.-From the same.

Annuaire des Marées des Côtes de France, pour l'An 1861. Par MM. Chazallon et Gausin. 12mo.-From the same.

French Admiralty Charts.-From the same.

Norges Mynter i middelalderen samlede og beskrevne. Af c. I. Schive. Parts 1-3.-From the Royal University of Christiania.

Fortællinger om Keiser Karl Magnus og Hans Jævninger I Norsk bearbeidelse fra det trettende aarhundrede udgivet af $\mathrm{C}$. $\mathrm{R}$.

Unger I. 8vo. Christiania. 1860.-From the same.

Forhandlinger i videnskabs-selskabet. Christiania. 1860. 8vo.From the same. 
Det Kongelige Norske Frederiks Universitets Stiftelse, \&c., af M. J. Monrad. 8vo. Christiania. 1861.-From the same.

Orersight af Norges Echinodermer. Ved Dr Michael Sars. Christiania. 1861. 8vo.-From the same.

Nyt Magazin for Naturvidenskaberne. Hefte III., IV. 1861.From the same.

Norske Plantenavne. Af J. Hafen. 8vo. 1860.-From the same. Notice sur la Saga de Charlemagne. 8vo.-From the same.

Om Cirklers Berqring. Af C. M. Guldberg. 4to. 1861.-From the same.

Om Kometbanernes indbyrdes Beliggenhed. Af $\mathrm{H}$. Mohn. 4to. 1861.-From the same.

Om Siphonodentalium Vitreum en ny slægt og art af dentalidernes Familie. Af Dr Michael Sars. 4to. 1861.-From the same.

Index Scholarum in Universitate regia Fredericiana, 1861. 4to.From the same.

Solennia Academica Universitatis Literariæ Regiæ Fredericianæ. 4to. 1861.-From the same.

Cantate ved Det Norske Universitets Halvhnndredaarsfest. 4to. 1861.-From the same.

Thirty-Fourth Annual Report of the Royal Scottish Academy. 8vo. -From the Academy.

Proceedings of the Royal Horticultural Society, No. XXXI. 8vo. -From the Society.

Observations and Experiments on the Carcinus Mœnas. By W. Carmichael M'Intosh, M.D. 8vo. 1861.-From the Author. Journal of the Statistical Society of London. Vol. XXIV., Part 4. 8vo.-From the Society.

Sitzungsberichte der Königl. Bayer. Akademie der Wissenschaften zu München. 1861. Heft IV. 8vo.-From the Academy.

Mémorie della Reale Accademia della Scienze di Torino. Tomo XIX. 1861. 4to.-From the Academy.

Nova Acta Regiae Societatis Scientiarum Upsaliensis. Vol. III. 1861. 4to.-From the Society.

Arsskrift utgifven af Konigl. Vetenskaps-Societetem i Upsala argangen II. 8vo.-From the same.

Mémoires de la Société de Physique et d'Histoire Naturelle de Genève. Tome XVI., Part 1.-From the Society. 
Atti dell' Imp.-Reg. Istituto Veneto di Scienze, Littere ed Arti. Vol. VI. Parts 7-9. 8vo.-From the Institute.

Arc du Meridien de $25^{\circ} 20^{\prime}$ entre le Danube et la Mer Glaciale. Tome I., II. 4to. With an Atlas.-From the Royal Academy of Sciences, St Petersburg.

Mémoires de l'Académie Imp. des Sciences de St Petersbourg. Tome IV., No. 1. 4to._From the same.

Tabulæ Quantitatum Berselianarum. 1840-1846. 8vo.-From the same.

Sitzungsberichte der Kaiserlichen Akademie der Wissenschaften. Math.-Nat. Classe. B. XLII., No. 29 ; B. XLIII., Heft 3-5; B. XLIV., Heft 1, 2.-Phil.-Hist. Classe. B. XXXVI., Heft 3; B. XXXVII., Heft 1-4. 8vo. Wien.-From the Academy.

Denkschriften der Kaiserlichen Akadémie der Wissenschaften. Phil.Hist. Classe. B. XI. 4to.-From the same.

Jahrbuch der Kaiserlich-Königlichen Geologischen Reichsanstalt. B. XI. 8vo.-From the same.

Almanach der Kaiserlichen Akademie der Wissenschaften. Wien. 1861. 8vo.-From the same.

Annales de l'Observatoire Physique Central de Russie. Année 1858.

Nos. 1, 2. 4to.--From the Observatory of St Petersburg.

Compte Rendu Annuel. 1859-60. 4to.-From the same.

Beobachtungen und Elemente des Cometen. II. 1860. Von. O.

Struve. 8vo.-From the Author.

Bemerkungen über den dritten Cometen von 1860. Von Dr A.

Winnecke. 8vo.-From the Author.

Uber einen vom Gen. Schubert an die Akademie gerichteten Antrag,

betreffend die Russ-Scand. Meridian-Gradmessung. Von $O$.

Struve. 8vo.-From the Author.

Abstracts of Spirit-Levelling in Scotland. By Col. Sir Henry James.

1861. 4to.-From the Ordnance Survey.

American Journal of Science and Arts. No. 96. 8vo.-From the Editors.

Report of the Topographical and Geographical Exploration of the

Western Districts of the Nelson Province, New Zealand. 8vo.

1861.-From the Protincial Secretary's Office, Nelson.

Proceedings of the Acidemy of Natural Sciences, Philadelphia. 8ro.

-From the Academy. 
Quarterly Journal of the Geological Society. No. 68. 8vo.-From the Society.

Abstracts of the Geological Society of London. No. 72. 8vo.From the Society.

Monthly Notice of the Royal Astronomical Society. November 1861. 8vo.-From the Society.

Monthly Returns of Births, Deaths, and Marriages. November 1861. 8vo.-From the Registrar-General.

On the Concrete used in the late Extension of the London Docks. By George Robertson, C.E. 8vo.-From the Author.

An Investigation into the Theory and Practice of Hydraulic Mortar. By George Robertson, C.E.-From the Author.

Monday, 20th Junuary 1862.

JAMES T. GIBSON-CRAIG, Esq., Treasurer, in the Chair.

The following Communications were read :-

1. Note on the Phosphorescence of Beröe. By Professor Allman.

The author stated, as the results of some experiments which he had made on the phosphorescence of a species of Beröe (Idyia) which abounded during the last summer in the Firth of Forth, that the light is never emitted as long as the animal is exposed to daylight; and that withdrawal from the daylight for some time is necessary, in order to impart to the Beröe the property of phosphorescence.

A glass jar, containing several living specimens of the Beröe in sea water, was removed from the daylight into a dark room, when not the slightest indication of phosphorescence could be detected, though the animals were subjected to precisely the same kind of irritation as is found to be always followed by the emission of light during the night. But after the Beröes had remained for about twenty minutes in the dark, the phosphorescence had become as vivid as by night; the slightest irritation would call it forth, and the vibration communicated to the jar by a blow on the table where it lay, was 